\title{
EMOTIONAL LABOUR IN THE ROLE OF UNIVERSITY DEPARTMENT CHAIR
}

SUMMER COWLEY

Ontario Institute for Studies in Education, University of Toronto

\begin{abstract}
When considering the role of university department chair, one may think of objective tasks, such as budgets, scheduling, and faculty development. However, due to the social interaction required to run a department, the daily work of chair involves emotional self-management in addition to planning and organization. Although the objective tasks of the role of chair have been studied, there is a lack of information regarding chairs' self-management of emotions, a process herein referred to as emotional labour. This study asks: "In what ways do department chairs perform emotional labour at work?" Findings from this study may shed light on the ways in which the role of university department chair in Canada requires emotional work, as well as objective task-completion.
\end{abstract}

Keywords: department chairs, higher education, emotional labour, emotions 


\section{Emotional Labour in the Role of University Department Chair}

Consider the work of a university department chair (or head) and various tasks may come to mind. These tasks may include the chair's mandated activities of budgeting, scheduling teaching hours, running departmental meetings, and holding individual meetings regarding grievances, suggestions, and professorial career goals. According to chair job descriptions and university policies (University of Alberta, 2009a, 2009b; University of Toronto, 2003; University of British Columbia, 2016, n.d.; McGill University, 2017), successful completion of these tasks can be measured through balanced finances, manageable schedules, regular departmental planning and discussion, and successful applications for grants, promotion, and tenure. The role may appear to require largely objective reasoning to achieve quantifiable ends. However, the daily work life of a department chair focuses so much on interactions with others (McMaster University, 2000; University of Toronto, 2003; University of Alberta, 2009a, 2009b) that a chair's personal experience of their role may centre more closely around relationship-related successes and failures than the objective tasks assigned to them. That is, the work of being chair may be closely linked to the delicate socially-bound work required to build and maintain positive collegial relationships and develop an excellent personal reputation. In this study, department chairs were interviewed to discuss the role of emotional labour (Hochschild, 2003) in their daily work as chair. The objective of this study is to answer the question: "In what ways do department chairs perform emotional labour at work?" Findings from this study help to build knowledge on the emotional effort required to be chair, expanding current conceptualizations of the chairship as a task-oriented role.

In contrast to depictions of the role of department chair as highly administrative, participants in this study emphasized the significance of relationship-maintenance and building through emotional self-management. Participants in this study, in discussing their emotional labour at work, described the ways in which they strove to appear positive, calm, and neutral while at work. An awareness of this potential "ideal" mode of emotional expression may help current and prospective chairs, higher education researchers, and upper administration to understand the experience of the role further beyond its task-oriented nature. By considering the ways in which the participants in this study characterized their emotional self-management, prospective chairs may be able to better understand the hidden requirements of the role, upper administrators may be able to plan further professional development and support for chairs, and chairs' colleagues, staff, and students may be able to more carefully consider the role of chair as emotionally taxing. In short, findings from this study may help chairs and those with whom they interact to consider that department chairs must work to complete their tasks and duties while also working to rein in their emotions at work. Although any consideration of chairs' emotional self-management at work would add to conversations surrounding the nature of the role, one must ask whether such self-management is always beneficial for individual chairs. Is feigned positivity, calm, or neutrality necessarily a worthwhile goal? Throughout the following discussion of this study, one must consider the significance of "masking" emotions (Hochschild, 
2003) while in service to others and the possible effects on chairs' sense of being authentic and on their colleagues' perceptions of their authenticity.

\section{Theoretical Framework and Overview}

This study uses Hochschild's (2003) framework of emotional labour as a lens. Hochschild (2003) defined the term 'emotional labour' in her study of public service workers, as she noted the effort that they had to expend on portraying a particular affect. Hochschild (2003) describes three factors as relevant to discussions of emotional labour: social exchange, feeling rules, and emotion work. In situations where emotional labour is being performed, we can say that: a) social exchange is constrained to formal avenues whose motives are profit-based; b) socially-constructed norms (feeling rules) exist that define and constrain what emotional expression is appropriate, and c) emotion work is performed by social agents who wish to obey those rules. Hochschild's (2003) description of feeling rules at work focuses on the effort required to meet norms of emotional expression. If "emotion workers" (Hochschild, 2003) did not display the prescribed emotions, they would be perceived as not meeting the normative expectations of their roles; they would be seen as doing a bad job.

By commodifying feeling and its expression, institutions are able to shape the ways in which workers express themselves and the ways in which they think about self-expression. In universities, although the 'rule books' are much slimmer than the training manuals described in Hochschild (2003), workers are still held to the standard of an imagined, normative, ideal —in the case of department chairs, this is the ideal of 'the good leader'. The norms surrounding 'the good leader' and their emotional expression represent a standard which chairs in this study described as expected of them in their role. In the transition from regular faculty to chair, the role of chairs changes from focusing on private and individualistic concerns to public and group concerns (Gmelch \& Parkay, 1999). Chairs must learn how they are expected to act, including the feeling rules that outline which emotions are appropriate for them to express at work. Investigating the emotional labour that chairs must perform in order to maintain positive work relationships and their professional and personal reputations at work may allow us to better understand the stress that can result from that effort.

From my review of relevant literature, it appears that only one study on this specific topic currently exists - Gonzales and Rincones (2013) — an exploratory study of the emotional labour of one university department chair. Studies that expand on their work, or on chairs' emotional labour in general, have either not been conducted or have yet to be published. My study continues the exploration of the emotional labour of department chairs through interviews often chairs from diverse areas of study at one large research-intensive university in Canada as casestudy. Due to varying preferred modes of communication, the chairs in this study provided information via: face-to-face, telephone, and Skype interviews; email correspondence, and (in one case) participant journal entries. The chairs answered questions about the emotional labour they performed as part of their role, the feeling rules that defined how they should and should not express emotions at work, and the ways in which those rules were written and rewritten. The 
resulting data were coded, categorized, and analyzed for themes. The analysis of the data culminated in an overarching concept: university department chairs perform emotional labour in order to appear positive, calm, and neutral at work. The chairs generally considered the feeling rules guiding their performance of emotional labour as self-created but, as each chair described a similar set of rules, these rules may be thought of as symptomatic of a set of internalized norms surrounding university administrator emotional expression.

\section{Context for the Study}

One difficulty of studying department chair emotional labour is the lack of literature published on the specific topic. Emotional labour has been studied in areas connected to the industry of higher education, including nursing (Muller-Juge et al., 2014), K-12 teaching and administration (Maxwell \& Riley, 2016), university instruction (Constanti \& Gibbs, 2004), customer service, and business leadership (Kaiser \& Kaplan, 2006). In these fields, emotional labour has been described as relevant to the worker's ability to perform mandatory tasks or to navigate significant work relationships. Despite the recorded significance of emotional labour in many areas of work (and non-work life), little attention has been paid in the literature to the emotional labour of department chairs or other university administrators. Gonzales and Rincones (2013) described and analyzed the emotional labour of one department chair in an American university but little other work on chair emotions exists. This is perhaps a reflection of the broader tendency in higher education research to treat universities as sites of thought, objectivity, and knowledge creation (Mumby \& Putnam, 1992; Luthar \& Šadl, 2008), rather than as sites of emotions or complex social relationships. The areas of research that frame this study are: emotions in higher education; emotional labour in K-12, university instruction, and various other industries; and task-oriented work/ emotional labour in the role of department chairs.

\section{Emotional Labour in Education}

The role of department chair is a social one and the regular tasks of a chair are largely performed with or for others, rather than alone and for oneself (DeFleur, Kurpius, Osborne, \& Hamilton, 2010). Literature on emotional labour in higher education leadership is limited (Gonzales \& Rincones, 2013), in contrast to the wealth of studies conducted on the emotional labour of teachers and course instructors (Bellas, 1999; Berry \& Cassidy, 2013; Constanti \& Gibbs, 2004; Ogbonna \& Harris, 2004; Zhang \& Zhu, 2008). Hargreaves (1998) focuses on the emotional labour of the teachers that leaders must manage and develop and only briefly addresses the emotional labour of educational leaders. Looking slightly further afield, Maxwell and Riley's (2016) study on school principals offers some insight into the emotional labour of these types of educational leaders and finds that regulating emotions through suppression or forced expression affected both burnout and job satisfaction. Zhang and Zhu (2008) conduct a study similar to Maxwell and Riley (2016) but within a higher education context and note the connections between emotional labour, burnout, and job satisfaction in the working lives of college instructors in China. As mentioned, many authors writing about emotional labour in 
higher education focus on instructors. Constanti and Gibbs (2004) found that the necessity of performances of emotional labour could lead to exploitation of workers in order to satisfy the students and further the goals of management. Moreover, writing about university instructors, Bellas (1999) points out the differences in the expected emotional labour capabilities of women and men; Bellas notes that, despite the large amount of emotional labour required of Professors, this type of work tends to be undervalued and unrewarded within the organizational context. Writing on the emotional lives of five leaders in an educational context, Beatty (2000) describes emotional self-regulation by leaders as a challenging part of a working in particular organizational cultures and describes emotional regulation as connected to job satisfaction, similar to other authors mentioned earlier.

\section{Department Chair as a Social Role}

The role of department chair is a social one. This is partly due to the position of the chairship in a boundary space between upper administration and departmental faculty, where chairs must navigate complex relationships as they carry out their work (Armstrong \& Woloshyn, 2017). Within this position of institutional messenger and collegial advocate, chairs may use informal personal connections or professional authority as the attempt to carry out the actions dictated by administrators higher up the hierarchical chain (Berdrow, 2010). While the work required by department chairs to create and maintain collegial work relationships has been described in the literature as significant (Brown \& Moshavi, 2002; Leary, Sullivan, \& Ray, 2001; Sarros, Wolverton, Gmelch, \& Wolverton, 1999), the role of chair is routinely portrayed as challenging because of its complexity, ambiguity, and multifaceted nature (Aziz et al., 2005; Boyko \& Jones, 2010; Boyko, 2009; Gmelch \& Burns, 1994; Sarros et al, 1999). The complexity and challenge of the chairship extends to a need for the ability to develop and nurture positive departmental atmospheres (Brown \& Moshavi, 2002; Leary et al, 2001; Sarros at al, 1999). Additionally, U15 department job descriptions of the role points to a need for chairs with welldeveloped interpersonal skills (University of Alberta, 2009a, 2009b; University of British Columbia, n.d., 2016; University of Toronto, 2016). Chair job descriptions emphasise building collegial environments, departmental vision, and unity. This indicates that the role requires relationship-building abilities as a vital feature of the chair.

In general, the chairship has been described as difficult to transition into from a general faculty position (Wolverton, Ackerman, \& Holt, 2005; DeFleur et al, 2010). Practical tips on how to "survive" and taking on the role of chair and the associated changes to one's work relationships and tasks (Buller, 2012; Chu, 2012; DeLander, 2017; Taggart, 2015). Despite best practices guides, literature on educational leadership lacks a consensus on the best way to lead (Bush \& Glover, 2014). Bryman (2007) identifies "13 aspects of leader behaviour that were found to be associated with effectiveness at departmental level" (p. 696) in a review of literature from 1985-2006. Of the 13 aspects discussed, at least five are concerned with the social role of the chairship. These five socially-oriented aspects are as follow: consideration for others, trustworthiness and integrity, fostering open communication, acting as a role model, and creating 
a positive and collegial work environment. Bryman's (2007) identification of these sociallyoriented factors, along with U15 job descriptions of the role of chair, indicates an apparent significance of social and interpersonal tasks and capabilities for department chairs.

\section{Literature Review Summary}

Overall, the emotional lives of department chairs at work are understudied. The same claim could be made about many of the roles of university academics or administrators. In this study, department chairs were partly chosen as a focal point because of their significance to departmental functioning (Czech \& Forward, 2010). They were also chosen because of the closeness of their position to the professors, students, and staff in their departments, as opposed to upper administration's more removed position. During the planning stage of this study, it was hoped that department chairs, because of the social nature of their role, might be able to easily recall moments or circumstances in which they had to perform emotional labour as part of their role. In corresponding with ten current chairs, this hope proved to be well-founded.

\section{Methodology and Methods}

A case study design for this research question is appropriate because of case study's focus on the significance of context. Merriam (2009) writes that case studies are appropriate when the phenomenon of interest cannot be removed from its context, when the context is within a bounded system, and where data are drawn from multiple data sources. This case study used individual interviews and participant journals (Jacelon \& Imperio, 2005) as data collection methods. Ten current department chairs in the natural and social sciences, the arts, and professional faculties were interviewed. The chairs ranged in tenure from 3 months to over 6 years, were female and male, and North American and European in national origins. Data were collected via in-person interviews, participant journals, and skype, telephone, and email correspondence. In-person interviews were 60-90 minutes long, and the secondary Skype/telephone interviews were 45-60 minutes long. One chair chose to keep a participant journal and did so with 10 entries written on weekdays over a two-week period. Data collection occurred from November 2016 through March 2017. The research site was a large, researchintensive university in Canada with over 70 departments. Data were analyzed using Saldaña's (2016) affective methods of first cycle coding, focusing on instances where chairs spoke of emotions and values. Codes were identified and noted line by line in Excel as instances of the $a$ priori code of 'emotional labour'; in vivo codes of the participants' words in transcripts relating to emotional labour; and emotion and value codes. Codes were organized into categories using a coding table in Excel and a table top method to identify themes (Saldaña, 2016).

\section{Research Site and Participants}

This qualitative case study, conducted in the format described by Merriam (2009) and Stake $(1995 ; 2013)$ was conducted at an institution comprising over 70 departments. The purpose of conducting the study at a large university was to highlight some of the problems for chairs that 
scholars in this field have discussed (Boyko \& Jones, 2010; Gmelch \& Parkay, 1999; Gmelch, Tanewski, \& Sarros, 1998), i.e. feeling isolated, bogged down by 'administrivia' in a large and complex bureaucratic structure, unprepared and untrained as managers. The research site was a Canadian university with a student population of over 30,000 undergraduate students and over 7,000 graduate students. Only current department chairs were invited to participate, in an effort to avoid the complicating effects of time on memory. Each department chair who participated in this study was serving a full five-year term. In order to include responses from chairs with as varied a range of demographic backgrounds as possible, Participants were recruited based on variation in experience in the role, and gender. Participants were actively sought out from across the Faculties of: Arts and Science, the professional faculties (Dentistry, Education, Engineering, Law, Medicine, Nursing), and the non-professional faculties. The ten chairs who accepted my invitations were from the natural sciences, arts, and the professional faculties, and varied in previous experience and participation in an on-site leadership development program (Table 1).

\begin{tabular}{|c|c|c|c|c|}
\hline \multicolumn{5}{|c|}{ Participants } \\
\hline Chair & Data sources & $\begin{array}{l}\text { Participation in } \\
\text { leadership } \\
\text { program }\end{array}$ & $\begin{array}{l}\text { Previous university } \\
\text { leadership experience }\end{array}$ & Discipline \\
\hline $\mathrm{C} 1$ & $\begin{array}{l}\text { In-person } \\
\text { Interview x1 }\end{array}$ & no & no & Arts \\
\hline $\mathrm{C} 2$ & $\begin{array}{l}\text { In-person } \\
\text { Interview x } 2\end{array}$ & no & no & Arts \\
\hline C3 & $\begin{array}{l}\text { In-person } \\
\text { interview x1, } \\
\text { telephone } \\
\text { interview x1, } \\
\text { participant } \\
\text { journal }\end{array}$ & yes & no & Sciences \\
\hline $\mathrm{C} 4$ & $\begin{array}{l}\text { In-person } \\
\text { interview x1 }\end{array}$ & yes & no & Arts \\
\hline
\end{tabular}




\begin{tabular}{|c|c|c|c|c|}
\hline C5 & $\begin{array}{l}\text { In-person } \\
\text { interview x1, } \\
\text { Skype interview } \\
\text { x1 }\end{array}$ & no & yes & $\begin{array}{l}\text { Professional } \\
\text { faculty }\end{array}$ \\
\hline C6 & $\begin{array}{l}\text { In-person } \\
\text { interview, email } \\
\text { follow-up } \\
\text { questions }\end{array}$ & yes & no & Sciences \\
\hline C7 & $\begin{array}{l}\text { In-person } \\
\text { interview } x 1\end{array}$ & yes & yes & Arts \\
\hline $\mathrm{C} 8$ & $\begin{array}{l}\text { In-person } \\
\text { interview x1, } \\
\text { email } \\
\text { correspondence }\end{array}$ & no & yes & Sciences \\
\hline C9 & $\begin{array}{l}\text { In-person } \\
\text { interview } x 1\end{array}$ & no & yes & $\begin{array}{l}\text { Professional } \\
\text { faculty }\end{array}$ \\
\hline $\mathrm{C} 10$ & $\begin{array}{l}\text { In-person } \\
\text { interview x1 }\end{array}$ & & yes & Arts \\
\hline
\end{tabular}

Table 1. Participant data collection method and demographic information.

Interviews. The interviews that were conducted in this study were semi-structured (Merriam, 2009) in design and each one started with the same 10 questions, addressing emotional labour, emotion work feeling rules, and social exchange, as a guide, leaving me opportunities to ask follow-up questions in response to participants' statements.

Email Correspondence. Six of the chairs chose not to participate in a second interview but welcomed any follow-up questions to be sent via email after the interviews were transcribed. After each interview, the transcript of the recording was sent to the chair, with a request for them to make amendments to the transcripts as they saw fit. Summarizing notes and follow-up questions were also sent at this time. Three chairs sent responses to follow-up questions after the initial interviews via email. The chairs who responded to follow-up questions via email answered two to four written questions.

Participant Journals. The study was designed to include journal entries as a means of learning about chair emotional labour, in the hopes that the reflective act of journaling in relative 
privacy might draw out further insights about their daily work (Jacelon and Imperio, 2005). Only one chair chose to complete a participant journal; the other 9 chairs who did not complete journals did not provide a specific reason for no participating in this way but cited a lack of time as a factor in their limited participation choices in general. This chair completed a daily journal entry for two weeks. The chair's journal entries were short and focused on emotional suppression, expression, social exchange and emotions that he experienced at work.

\section{Data Presentation}

The chairs in this study exerted effort as part of a daily routine to meet a self-monitored standard of behaviour. The chairs were asked: "In what ways do chairs perform emotional labour at work?". Indicative of the responses of the participants as a whole, one chair said:

I think emotional labour happens every time I come into the office. Do I go and say hello to everybody in order to create a warmer environment, or do I go to my work? How do I write - what's the tone of my email? If I just want to get things done, what do I actually want to do to make the person that I'm writing to inclined to do something for me? I can't even imagine that- there's very few tasks that do not involve some kind of emotional labour. (C7)

As they performed regular emotional work, the chairs in this study described their attempts to meet a shared idealized standard of a 'good leader' in the university. They expressed a desire to be perceived as calm, confident, fearless, and rational as a leader. The chair gave positive examples of leaders who seemed unfazed by various events, were well-organized, and were open and direct about the challenges faced by the department without being overly negative. Chairs repeatedly described a need to act as a strong advocate and cheerleader for their department within the department and within the institution at large. Negative examples of chairs' emotional expression included situations when people were unable to maintain control of their emotions, or who were unrealistically positive. However, participants described ideal chair emotions as centred around positivity, calmness, and neutrality.

\section{Be Positive}

Overall, chairs agreed on the need for expressing positivity and optimism in their role. They emphasised the importance of a "positive attitude... toward the institution, the department, colleagues, just generally positive" (C8), though with an emphasis on finding a balance so that valid critiques could still be made. Chairs described the importance of expressing "positivity, more than anything else, optimism" (C5) as connected to advocacy, saying that "there's a certain sort of boosterism that goes along with it... To celebrate the accomplishments of the faculty, to be enthusiastic about the things that the faculty is doing" (C4) and to "be cheerleaders for our colleagues " (C9). One chair explained the drive to project positivity as related to doing a good job, saying: "if you're enthusiastic about your job and you bring an enthusiasm to your job and an interest in what other people's jobs are, then they'll be enthusiastic as well. And things are way 
more efficient if people are enthusiastic" (C8). Negativity was described as undesirable, even in situations where there are "serious resource constraints and budgetary constraints...try to be creative, try to find another solution...But so much negativity? Not good, Negativity is not good" (C3).

However, chairs also noted the importance of acknowledging that not all situations could be addressed with positivity. Speaking of a previous administrator who had been highly positive, even in negative situations, one chair commented that it felt like the person was "making light of [it]...it just seemed disingenuous after a while. Like, 'No. No, No! Nothing is that good all the time" (C6). The importance of acknowledging negative emotions associated with change and loss, such as sadness and regret, was emphasized by another chair, who said that it "actually helps people to work through the change, so being able to express that and thereby give other people permission to feel that, express that and work through it" (C5). However, chairs emphasized a need for positivity over negativity, including one chair, who said:

Optimism, I think optimism is hugely important. Is that an emotion? Especially in the last few years of the university its' been so much doom and gloom. We've had so many cutbacks, we've had so much constant- especially in the arts. Attack, attack, attack, attack, people retire, people not being replaced. It just feels like we get so much bad news. So, I think optimism is huge. (C1)

This optimistic public face was not seen as always being an easy feat, with one chair noting the work they put into appearing enthusiastic “...when you're being asked to do something that, say, you don't particularly want to do or particularly agree with...you end up having to sort of mirror the enthusiasm of the Dean“(C4). For the chairs who participated in this study, projecting positivity was seen as an integral part of the work of being chair.

\section{Stay Calm}

Aside from enthusiasm and positivity, chairs agreed that it was important to be perceived as in control of their emotions. One chair advised against chairs talking about being too busy, saying that doing so could make a person "come across as not being maybe in charge of yourself, knowing your environment. So then how can you represent us? I have no confidence in him or her. Because he or she feels overwhelmed. It's not good. It's not good for anything" (C3). The importance of projecting a sense of being calm and in control was echoed by other chairs in this study. One chair pointed to a positive example of a past acting chair in the department, saying:

The thing that I really admire about her and often think about — it's just hard-I don't know what was going on inside, but she was-like some of the most ludicrous things, it didn't matter what came up, you couldn't tell what was going on. She would listen, she was very constructive and calm, and I just really appreciated that because I do think that's, ideally, what I aspire to be like in all situations. To not have a knee-jerk response. (C6)

For this chair, the calmness of her former chair made her a role model for appropriate chair emotional expression. Many chairs in this study emphasized their efforts to remain calm, saying 
that in important situations they would exert a lot of self-discipline "to be just incredibly calm and patient and to not raise [their] voice to not overreact to anything" $(\mathrm{C} 1)$ and, despite their feelings about a particular situation, they would "suck it up. Really remain calm" (C3). The need to be perceived as calm and in control of their emotions ran throughout the chairs' interviews.

\section{Appear Neutral}

Chairs talked about the care that they took to give an impression of being not only calm but also of presenting a neutral front where their feelings and biases were more difficult to figure out from the outside. One chair related the perception of neutrality as tied to appearing to be unbiased, saying that "when you're just a faculty member, you can just fiercely, fiercely fight for your program but as the chair, you have to be completely bipartisan" $(\mathrm{C} 1)$, even when they had their existing biases about various programs in the department. However, that chair and others said that although "a chair does have to be pretty neutral.... Like anything else it can be carried too far. Folks have to know that you care" (C5). A chair who described themself as 'circumspect' said that their more detached emotional engagement "where you're not unfeeling but just sort of less deeply emotionally entangled in something" (C4) was both positive and negative, saying:

I can see it being sort of a positive and negative. Where you're not unfeeling but just sort of less deeply emotionally entangled in something. It can become harder to empathize maybe and harder to be intuitive and easier to be ambivalent. (C4)

One chair who described herself as more emotionally expressive agreed with the benefits of remaining removed emotionally, saying: "I learned that I'm more effective if I'm a little bit detached. So, if I'm not emotionally invested in something" (C1). Later, when discussing the feeling rules that she lived by as a chair, she reiterated her commitment to detachment, saying: "Detachment is now one of my words that I put into my rules, that I try to stay detached (C1). In fact, all of the chairs in this study believed that they had set rules for themselves and created their own guidelines for emotional expression and behaviour. The chairs described a shared belief in an ideal standard of leader behaviour: be positive, be calm, be neutral.

\section{Feeling Rule Sources}

Participating chairs described their self-management of emotional expression as selfguided, with little or infrequent feedback from their colleagues. The chairs were asked about who decided what emotions were appropriate to express at work and one North American chair responded, "That's really me, that's really my own internal assessment" $(\mathrm{C} 1)$. One chair stated that the guidelines of which emotions should be expressed had origins that were "[p]robably internal. Probably internal. I've not done any kind of self-analysis in any deep way but it seems to come internally. Like, no one tells you how to be chair. They really don't" (C2). Another chair was asked about the origin of the rules about emotional expression and said: "It's me, mostly myself, I think" (C3), and yet another chair said that they would "make a rule for myself" (C9). One other chair stated that she did not receive any external feedback on the rules, saying "I've never really been given feedback about anything being inappropriate. So, I guess it is pretty 
much internal and I guess I base it pretty much on my own assessment of how things have gone" (C1). The chairs in this study repeatedly talked about how normal the expectations for emotional expression were:

The rules are generally what you might expect. We expect people to be positive, business but don't be afraid to crack a joke once in a while, jokes at other people's expense are not cool. But in general, the rules are about what you expect. (C5)

The chairs described the rules as barely interesting at all, commonplace, or expected, saying: "I tend to be an optimistic person anyways" (C8); or "I don't show emotions very often and...very rarely, if ever, lose my temper" (C2). Overall, the chairs seemed to express a shared belief that the feeling rules governing their behaviour were personally-created, self-regulated, and normal. As part of their work as chair, participants in this study self-monitored and self-managed emotional expression in an aim to be perceived in a certain way — as positive, calm, and neutral.

\section{Analysis of Findings}

The participants in this study described regular and ongoing work that they had to perform as part of their role in order to manage their emotions at work. Within the data gathered from the 10 participants, a potential standard appeared of 'ideal' chair emotionality as positive, calm, and neutral. The standard within this study paints a picture of department chairs as operating with constrained emotional expression, limited in the range of emotions that they consider suitable at work. Although some of the chairs in this study did describe some misgivings about the emotionality that they felt was required of them within their role, each chair still adhered to the same basic standards of the positive, calm, and neutral chair. The work needed to project a positive, calm, and neutral emotional state required the chairs to notice, consider, and manage their emotions - a task different but not separate from the more traditional notion of the tasks of a "bean counting" department chair (Chu, 2012). In this small qualitative study, participants restricted their emotional expression to display positivity, calmness, and a neutral affect - emotions they believed would be perceived positively by their colleagues. The chairs' individual adherence to the same standard may point to the possible existence of an implicit social norm (Macionis \& Gerber, 2008). In order to examine whether a social norm for chair emotional expressiveness exists, further research is required that collects data from a larger number of participants across different disciplines in Canadian universities. Repeating this study on a larger scale might help to determine whether a standard of chair emotional expression exists across institutions and disciplines and, if a standard does exist, whether the standard is the same as the one identified in this study. Further research on this topic might help determine whether the standard described by chairs is a normative standard for chairs in general.

\section{New Managerialist \& Neo-liberal Tendencies}

Although chairs in this study appeared to share a standard of ideal chair behaviour, literature on educational leadership has not identified an agreed-upon best way to lead (Samad, 2015; Bensimon, Neumann, \& Birnbaum, 1989; Bush \& Glover, 2014; Bryman, 2007). There 
are indications that the lack of agreement may be related to differences in ideological, contextual, or practical aspects of leaders and institutions (Bush \& Glover, 2014). Despite the wide range in leadership styles described in the literature and in the practiced leadership styles of participating chairs in this study, the participants appeared to share a standard for leader emotional expression. The positive, calm, and neutral standard for chair emotions may reflect parts of new managerialist leadership, as chairs try to find a way to cheerfully convince colleagues to accept administrative decisions as being for the best. New managerialism is characteristically focused on efficiency, productivity, and profit (Deem, 1998; Deem \& Brehony, 2005; Hoyle \& Wallace, 2005; Leithwood, Jantzi, \& Steinbach, 1999). In the last two decades, new managerialism has been indicated as being as significant to educational leadership as the more 'people-focused' styles of charismatic and transformational leadership (Bass \& Avolio, 1994; Bush \& Glover, 2014; Brown \& Moshavi, 2002). Although no firm consensus on a 'best' style of theory of educational leadership exists, findings from this study may point to the practice of leadership by department chairs as leaning towards new managerial/neo-liberal concerns for some time (Deem \& Brehony, 2005; Deem, 1998; Deem, 2001; Ferlie, 1996).

\section{Conclusions and Future Work}

Participating chairs in this study self-managed emotional expression in order to be perceived as positive, calm, and neutral. To maintain these standards, chairs described ways in which they had to perform work that they had not been formally trained or prepared for, and that they had not expected to have to do. Participants in this study described the role as chair as involving far more work self-managing emotions to navigate collegial relationships and interactions than one might expect from existing descriptions of the chairship as task-oriented. However, despite comments by some of the participating chairs regarding their distaste for the character they felt they were expected to play, the chairs all still chose to project positivity, calm, and neutrality. The possible disconnect between the emotions that chairs feel and the ones that they display might be linked to dissatisfaction within the role. It is possible that, despite chairs' best efforts to remain authentic and honest about their stance on various issues within the department, they may feel forced by their role to filter their emotional responses at work in order to appear objective. That is, the emotional labour required in the role may not necessarily result in a more positive work experience for chairs themselves.

Future work on this topic might focus on the ways in which chairs' adherence to a standard of emotional expressiveness relates to other outcomes, such as stress, job satisfaction, or quality of relationships at work. In order to look at these issues in a broader context, a larger scale study across institutions is required, with a greater number of participants from each discipline group, to attempt to account for any disciplinary cultural differences. Future work on this topic could also expand the participant base to include university administrators in roles other than that of department chair, so as to determine whether a positive, calm, and neutral demeanour is a standard for university administrators in general. 


\section{References}

Armstrong, D. E., \& Woloshyn, V. E. (2017). Exploring the tensions and ambiguities of university department chairs. Canadian Journal of Higher Education, 47(1), 97-113.

Aziz, S., Mullins, M. E., Balzer, W. K., Grauer, E., Burnfield, J. L., Lodato, M. A., \& CohenPowless, M. A. (2005). Understanding the training needs of department chairs. Studies in Higher Education, 30(5), 571-593.

Bass, B. M., \& Avolio, B. J. (1994). Transformational leadership and organizational culture. The International Journal of Public Administration, 17(3-4), 541-554.

Beatty, B. R. (2000). The emotions of educational leadership: Breaking the silence. International Journal of Leadership in Education, 3(4), 331-357.

Bellas, M. L. (1999). Emotional labor in academia: The case of professors. The Annals of the American Academy of Political and Social Science, 561(1), 96-110.

Bensimon, E., Neumann, A., \& Birnbaum, R. (1989). Making sense of administrative leadership: The ' $L$ ' word in higher education (ASHE-ERIC Higher Education Report No. 1). Washington DC: Association for the Study of Higher Education.

Berdrow, I. (2010). King among kings: Understanding the role and responsibilities of the department chair in higher education. Educational Management Administration \& Leadership, 38(4), 499-514.

Berry, K., \& Cassidy, S. (2013). Emotional labour in university lecturers: Considerations for higher education institutions. Journal of Curriculum and Teaching, 2(2), 22-36.

Boyko, L. (2009). An examination of academic department chairs in Canadian universities. (Unpublished Doctoral Dissertation). University of Toronto, Canada.

Boyko, L., \& Jones, G. A. (2010). The roles and responsibilities of middle management (Chairs and Deans) in Canadian universities. In V. Meek, L. Goedegebuure, R. Santiago, T. Carvalho (eds) The changing dynamics of higher education middle management (pp. 83102). Netherlands: Springer.

Brown, F. W., \& Moshavi, D. (2002). Herding academic cats: Faculty reactions to transformational and contingent reward leadership by department chairs. Journal of Leadership \& Organizational Studies, 8(3), 79-93.

Bryman, A. (2007). Effective leadership in higher education: A literature review. Studies in Higher Education, 32(6), 693-710. doi:10.1080/03075070701685114

Buller, J. L., (2012). The essential department chair: A comprehensive desk reference (2nd ed.), San Francisco, CA: Jossey-Bass.

Burns, J. S., \& Gmelch, W. H. (1995). Stress factors and occupational roles of department chairs. Journal of Technology Studies, 21(1), 12-23.

Bush, T., \& Glover, D. (2014). School leadership models: What do we know? School Leadership \& Management, 34(5), 553-571. doi:10.1080/13632434.2014.928680

Chu, D. (2012). The department chair primer: what chairs need to know and do to make a difference (2nd ed.). San Francisco, CA: Jossey-Bass. 
Constanti, P., \& Gibbs, P. (2004). Higher education teachers and emotional labour. International Journal of Educational Management, 18(4), 243-249.

Czech, K., \& Forward, G. L. (2010). Leader communication: Faculty perceptions of the department chair. Communication Quarterly, 58(4), 431-457. doi:10.1080/01463373.2010.525158

Deem, R. (1998). 'New managerialism' and higher education: The management of performances and cultures in universities in the United Kingdom. International Studies in Sociology of Education, 8(1), 47-70.

Deem, R. (2001). Globalisation, New Managerialism, Academic Capitalism and Entrepreneurialism in Universities: Is the local dimension still important? Comparative Education, 37(1), 7-20.

Deem, R., \& Brehony, K. J. (2005). Management as ideology: The case of 'new managerialism' in higher education. Oxford Review of Education, 31(2), 217-235.

DeFleur, M. H., Kurpius, D. D., Osborne, A., \& Maxwell Hamilton, J. (2010). The masters: Creating a new generation of leaders for mass communication education and beyond. Communication Education, 59(1), 19-40.

DeLander, G. E. (2017). Lessons from a recovering department chair. American Journal of Pharmaceutical Education, 81(3), 1-3.

Ferlie, E. (1996). The new public management in action. Oxford University Press: USA.

Foster, B. L. (2006). From faculty to administrator: Like going to a new planet. New Directions for Higher Education, 134, 49-57. doi:10.1002/he.216

Gmelch, W. H, \& Miskin, V. D. (2004) Chairing an academic department (2nd ed.). Atwood Publishing.

Gmelch, W. H. (1991, April). Paying the price for Academic Leadership: department chair tradeoffs. Paper presented at the Annual Meeting of the American Educational Research Association, Chicago, IL.

Gmelch, W. H. (2004). The department chair's balancing acts. New Directions for Higher Education, 126, 69-84.

Gmelch, W. H., \& Burns, J. S. (1993). The cost of academic leadership: Department chair stress. Innovative Higher Education, 17(4), 259-270.

Gmelch, W. H., \& Burns, J. S. (1994). Sources of stress for academic department chairpersons. Journal of Educational Administration, 32(1), 79-94.

Gmelch, W. H., \& Gates, G. S. (1995, April). The stressful journey of the department chair: An academic in need of a compass and clock. Paper presented at American Educational Research Association, San Francisco, CA.

Gmelch, W. H., \& Miskin, V. D. (2011). Department chair leadership skills. Atwood Pub. Gmelch, W. H., \& Parkay, F. W. (1999, April). Becoming a department chair: Negotiating the transition from scholar to administrator. Paper presented at the Annual Meeting of the American Educational Research Association, Montreal, Ontario, Canada. 
Gmelch, W. H., Tanewski, G. A., \& Sarros, J. C. (1998). Role stress and satisfaction of academic department heads. International Journal of Business Studies: A Publication of the Faculty of Business Administration, Edith Cowan University, 6(1), 97-123.

Gmelch, W.H. (1995). Department chairs under siege: Resolving the web of conflict. New Directions for Higher Education. 92, 35-42.

Gmelch, W.H., \& Chan, W. (1995). Administrator stress and coping effectiveness: Implications for administrator evaluation and development. Journal of Personnel Evaluation in Education, 9(3), 275-285.

Gonaim, F. (2016). A department chair: A life guard without a life jacket. Higher Education Policy, 29(2), 272-286.

Gonzales, L.D., \& Rincones, R. (2013). Using participatory action research and photo methods to explore higher education administration as an emotional endeavor. The Qualitative Report, 18(32), 1-17.

Hargreaves, A. (1998). The emotional politics of teaching and teacher development: With implications for educational leadership. International Journal of Leadership in Education, 1(4), 315-336.

Hochschild, A. (2003). The managed heart: Commercialization of human feeling. Berkeley, CA: University of California Press.

Hoyle, E., \& Wallace, M. (2005). Educational leadership: Ambiguity, professionals and managerialism. Sage.

Jacelon, C., \& Imperio, K. (2005). Participant diaries as a source of data in research with older adults. Qualitative Health Research, 15(7), 991-997.

Jenkins, R. (2009). What new department chairs need to know. Chronicle of Higher Education, 56(9), 40-42.

Kaiser, R. B., \& Kaplan, R. B. (2006). The deeper work of executive development: Outgrowing sensitivities. Academy of Management Learning \& Education, 5(4), 463-483.

Leary, P. A., Sullivan, M. E., \& Ray, D. (2001). The relationship of leadership styles of selected West Virginia deans and department chairs to job satisfaction of departmental faculty members. National FORUM of Educational Administration and Supervision Journal, 17(4), 205-215.

Leithwood, K., Jantzi, D., \& Steinbach, R. (1999). Changing leadership for changing times. McGraw-Hill Education.

Luthar, B., \& Šadl, Z. (2008). Communication and emotion in gendered organization: The hidden transcripts of power in higher education. J. E. Canaan \& W. Shumar, (Eds.), (2008). Structure and agency in the neoliberal university (pp. 211-233). New York, NY: Routledge.

Macionis, J. J, \& Gerber, L. M. (2008). Sociology. (6th Canadian ed.). Toronto: Pearson Prentice Hall. 
Maxwell, A., \& Riley, P. (2016). Emotional demands, emotional labour and occupational outcomes in school principals: Modelling the relationships. Educational Management Administration \& Leadership, 45(3). doi:10.1177/1741143215607878

McGill University. (2017). Academic Administrative Appointment Process. Montreal, QC.

McMaster University (2000). Terms of Reference for department chairs. Retrieved from http://www.mcmaster.ca/policy/AdminAcad/AdminProcedures/Chairs-DirectorsTermsofReference.pdf

Merriam, S. B. (2009). Qualitative research: A guide to design and implementation (2nd ed.). San Francisco, CA: Jossey-Bass.

Muller-Juge, V., Cullati, S., Blondon, K. S., Hudelson, P., Maitre, F., Vu, N. V., \& Nendaz, M. R. (2014). Interprofessional collaboration between residents and nurses in general internal medicine: A qualitative study on behaviours enhancing teamwork quality. PloS one, 9(4). doi:10.1371/journal.pone.0096160

Mumby, D. K., \& Putnam, L. L. (1992). The politics of emotion: A feminist reading of bounded rationality. Academy of Management Review, 17(3), 465-486.

Ogbonna, E., \& Harris, L. C. (2004). Work intensification and emotional labour among UK university lecturers: An exploratory study. Organization Studies, 25(7), 1185-1203.

Saldaña, J. (2016). The coding manual for qualitative researchers ( $3^{\text {rd }}$ ed.). Los Angeles, USA: Sage.

Samad, A. (2015). Towards an understanding of the effect of leadership on employee wellbeing and organizational outcomes in Australian universities. The Journal of Developing Areas, 49(6), 441-448.

Sarros, J.C., Wolverton, M., Gmelch, W.H., \& Wolverton, M.L., (1999). Stress in academic leadership: U.S. and Australian department chairs/heads. The Review of Higher Education, 22(2), 165-185.

Stake, R. E. (1995). The art of case study research. Thousand Oaks, CA: SAGE Publications.

Stake, R. E. (2013). Multiple case study analysis. New York, NY: Guilford Press.

Taggart, G. (2015). Department chair advice on teaching and research at U.S. research universities. Innovative Higher Education, 40(5), 443-454. doi:10.1007/s10755-0159329-4

U15. (2017). U15: About Us. Retrieved July 20, 2017, from http://u15.ca/about-us

University of Alberta. (2009a). Selection of department chairs Procedure (Appendix A): Roles and Responsibilities. Edmonton, AB.

University of Alberta. (2009b). Selection of department chairs Procedure (Appendix B): Terms and Conditions for department chairs. Edmonton, AB.

University of British Columbia (n.d.). Selection process for heads - Academic. Retrieved from https://academic.ubc.ca/sites/vpa.ubc.ca/files/documents/Guidelines_appthead.pdf

University of British Columbia. (2016). Appointments and extension of appointments for heads of academic units. Retrieved from http://universitycounsel.ubc.ca/files/2016/12/policy22.pdf 
University of Toronto. (2003). Policy on appointment of academic administrators. Retrieved from http://www.governingcouncil.utoronto.ca/Assets/Governing+Council+Digital+Assets/Pol icies/PDF/ppoct302003i.pdf

Wolverton, M., Ackerman, R., \& Holt, S. (2005). Preparing for leadership: What academic department chairs need to know. Journal of Higher Education Policy \& Management, 27(2), 227-238. doi:10.1080/13600800500120126

Zhang, Q., \& Zhu, W. (2008). Exploring emotion in teaching: Emotional labor, burnout, and satisfaction in Chinese higher education. Communication Education, 57(1), 105-122. 